\title{
AN INTEGRATED APPROACH FOR PETROPHYSICAL EVALUATION OF SHALY SAND RESERVOIRS IN SIMIAN FIELD, NILE DELTA,EGYPT
}

\author{
Mahmoud, H. M. ${ }^{1}$ and Abou Ashour, N. M. H. ${ }^{2}$ \\ 1 Rashid Petroleum Company and \\ 2 Geophysics Dept., Fac. of Sc., Ain Shams Univ., Egypt
}

\begin{abstract}
Submarine channel complexes as in the Nile Delta province has complex geologic settings with a great degree of heterogeneity in reservoir properties, so this study will focus on the study of general geological setting in Simian field in Nile Delta, in addition to the study of the petrophysical, and sedimentological characteristics of the upper Pliocene reservoir rocks of Wastani formation in Simian field. Such studies are intended to improve the process of reserve estimation of the study area.

The study includes calculation of petrophysical parameters for Simian reservoir rocks using advanced and conventional logging tools in the available wells to create lithology saturation cross plots and the lithologic identification cross plots, clay minerals identification, introducing the lateral variation of the lithology and the different saturation distribution in the Pliocene reservoir and comparison of different petrophysical results to select the proper approach that can fit with channelized system to get accurate petrophysical parameters considering all the uncertainty related to reserve calculation to optimize the further development activity.
\end{abstract}

Keywords: Shaly Sand Reservoir, CMR tool, FMI tool and Simian Field.

\section{INTRODUCTION}

Nile delta reservoirs mostly are shaly sand reservoirs and it is known that shaly sand reservoir interpretation is still sprouting with numerous researchers conducting investigations of the clay minerals effect on rock conductivity through the theoretical and experimental approach. The formation parameters such as porosity, permeability, water saturation and lithology are usually obtained from log analysis. The dominant function of those parameters is to assess the hydrocarbon content of subsurface formations and that will be our main objective in this study focusing on Simian field in offshore Nile Delta.

Simian field is a Pliocene gas field located in the eastern part of West Delta Deep Marine area, Mediterranean sea, Egypt, covers an area of about $200 \mathrm{~km}^{2}$, comprise a complex submarine channel system consisting of varying reservoir quality sands with shaly sand and shale in background. There are 9 wells drilled in Simian field; 6 development wells and 3 exploratory wells. This study is focusing on available 5 wells only (Fig. 1).

The research methodology can be explained through the following items:

Geological studies by Studying the structure, stratigraphy and hydrocarbon potentiality of Nile Delta and especially Simian field in West Delta Deep marine concession.

Petrophysical Studies which includes petrophysical analysis and interpretation of the conventional tools such as Density, Neutron, and Spectral Gamma Ray and Resistivity and advanced logging tools such as CMR (Combinable Magnetic Resonance) and FMI (Formation Micro Imager) to define lithological and mineralogical characteristics of the studied Interval including thin lamina/sand fraction definition, determine the petrophysical parameters (total and effective porosities, fluid saturations, shale and matrix contents, permeability index, net sand and net pay of the studied intervals. 
Mahmoud, H. M. and AbouAshour, N. M. H.

Integrated study Integrate results of conventional logs and advanced logs to establish different cases for reserve estimation showing the impact of these results on the reserve and pay estimation especially for thin bedded and high shale content reservoirs which couldn't be defined by conventional workflow

Fig. 1: Simian Field Location

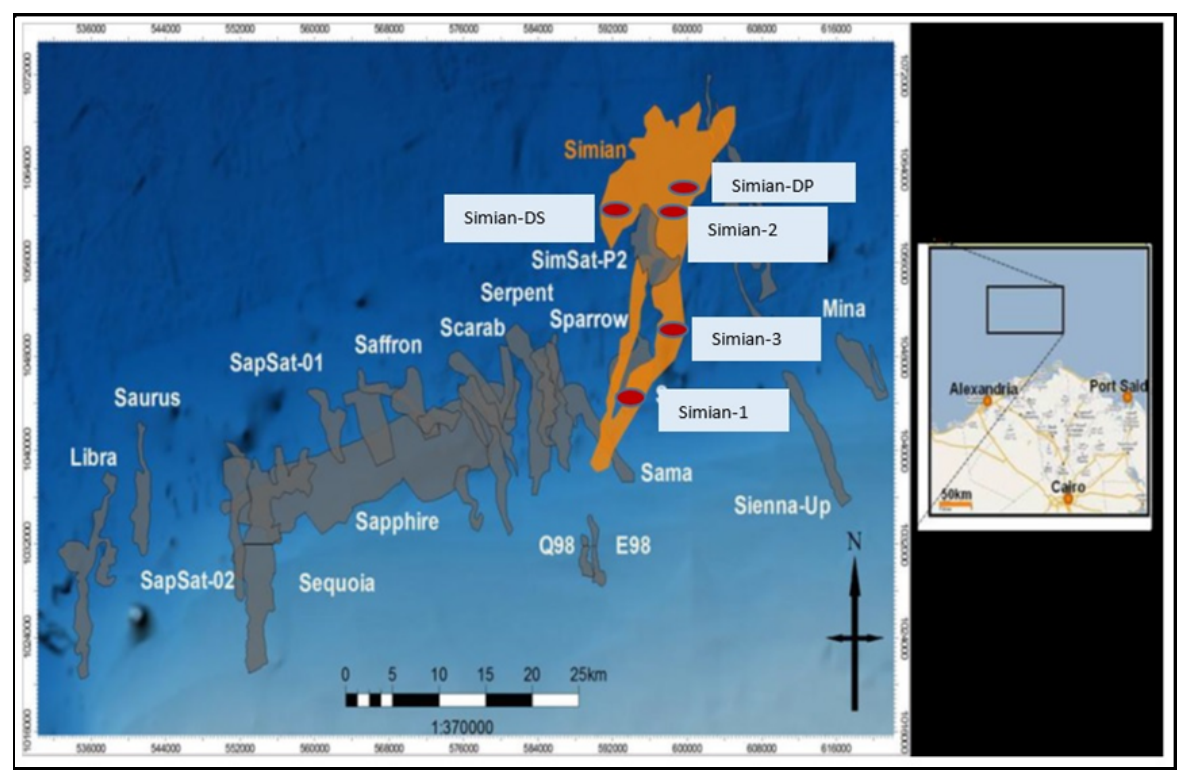

\section{General Geology}

The Nile Delta is actively extending into the Mediterranean and much of the underlying sediment is modern and relates to this seaward extension.

There is a complex pattern of distributary channels in the delta but two distributaries are dominant, the Rosetta Branch in the west and the Damietta Branch in the east. The majority of the delta is dominated by alluvial sediments similar to those found in the Nile Valley.

The Nile Delta has a complex structure due to the interference of several fault trends (Fig. 2 and 3), which are all parallel to the edges of the Mediterranean plate: NE-SW (Rosetta) fault system and E-W (NDOA) anticline.

NW-SE (Temsah) fault system. These fault trends are inherited from a pre-existing structural grain in the basement (Abdel Aal et al., 2000).

\section{Stratigraphic settings}

\section{a. Pre-Miocene}

During the Jurassic and Cretaceous a large carbonate platform was present in the area of the current Nile Delta (Harms and Wray, 1990). The "hinge line" (shown on Fig. 2) marks the northernmost progradation of the Cretaceous reefs and has strongly controlled subsequent sedimentation and faulting, with Tertiary clastics thickening significantly to the north of the hinge line (Dolson et al., 2005).

\section{b. Miocene (23.03 - $5.33 \mathrm{Ma})$}

Pre-Messinian (23.03 - 7.25 Ma): The ancestral Nile Delta became established in the Early/Middle Miocene, debouching into the Mediterranean at two separate eastern and western points (Dolson et al., 2005). During the Lower Miocene, the Mogra deltas prograded northwards in response to a forced regression (Fig. 3). Uplift in the Middle Miocene caused erosion and turbidite deposition deep in the basin (Nassar et al., 2012). In the Late Miocene, marine conditions were re-established resulting in the deposition of extensive marine sands and shales in the Serravallian (14.8 Ma) (Dolson et al., 2005). Delta progradation resumed during the Tortonian, depositing the Qawasim Formation and was followed by the Late Tortonian transgression. 
An intgrated approach for petrophysical evaluation

Messinian (7.25 - 5.33 Ma): Towards the end of the Miocene, erosional unconformities became increasingly common, culminating in the Messinian Salinity Crisis (MSC). The Mediterranean had become isolated after the tectonically-driven collision of Africa and Europe which caused the Straits of Gibraltar to close (Steininger and Rögl, 1984). This resulted in a major forced regression and the evaporation of the Mediterranean Sea which resulted in the deposition of extensive salts and anhydrite in offshore areas, (Barber, 1981; Popov et al., 2006; Rouchy and Caruso, 2006).

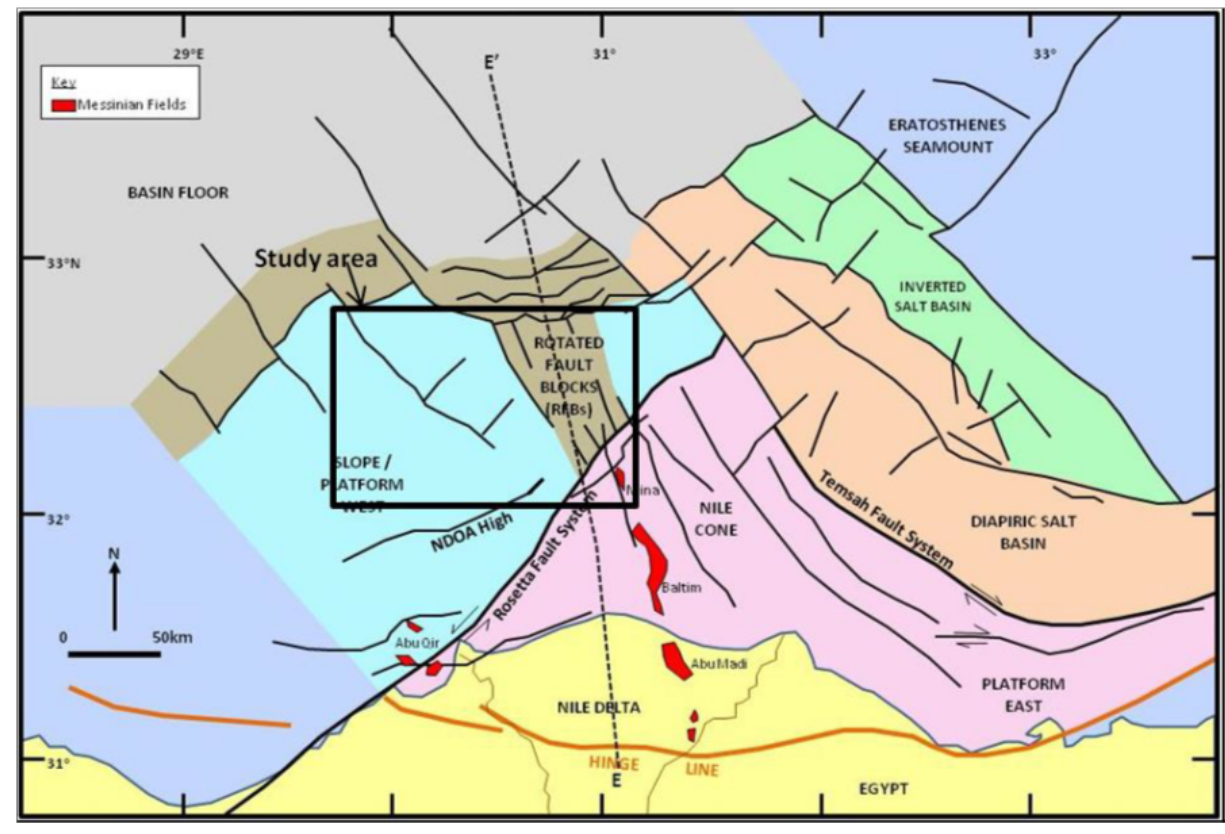

Fig. 2: Tectonic regions of the Nile Delta, (Abdel Aal et al., 2001).

Fig. 3: Geological cross-sections through the onshore and offshore Nile Delta, (Abdel Aal et al., 2001).

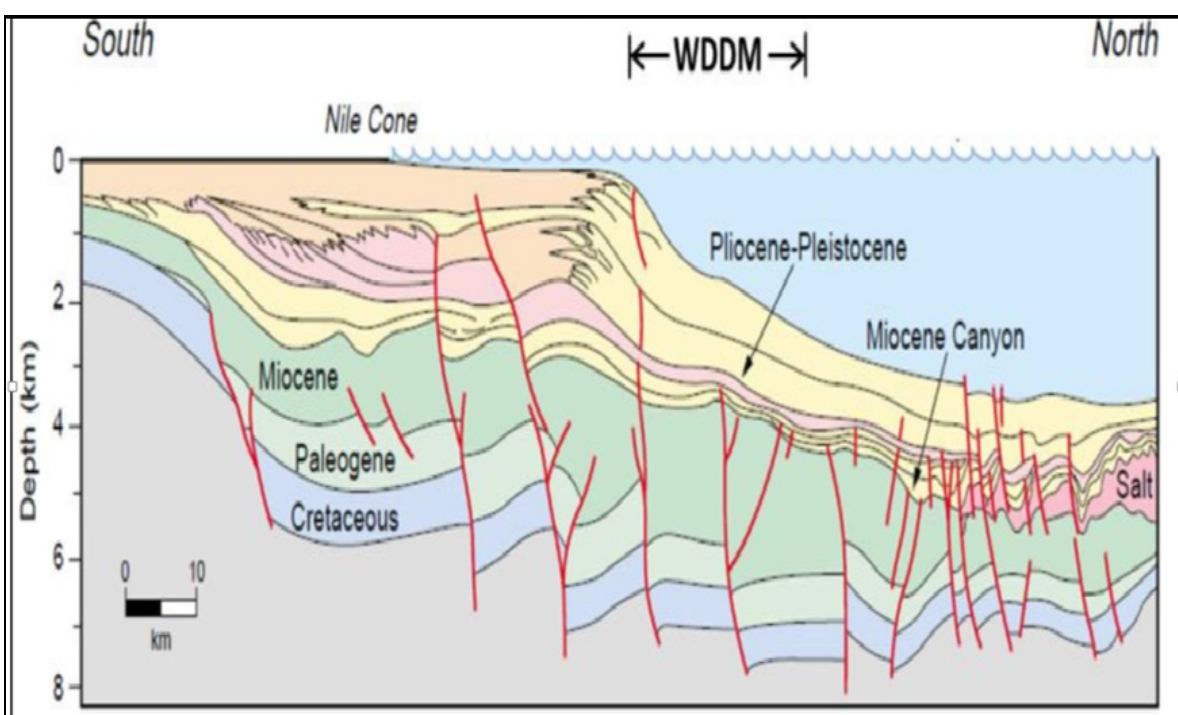

\section{Abu Madi Formation -Late Miocene- Early Pliocene}

\section{Messinian-Zanclian}

The Pliocene rocks in the Nile Delta region are subdivided into three formations (Rizzini et al. 1976), from base to top: Abu Madi, Kafr El Sheikh, and El Wastani. The Abu Madi Formation is fluvial sand at the basal part covered by interbedded and thick pebbly sand and shale. Kafr El Sheikh Formation is incised at the top by low stand and prograding clastics of El Wastani Formation. The Late Pliocene to Early Pleistocene is represented by El Wastani Formation that was deposited as a regressive sequence after a starvation event of the Kafr El Sheikh Formation. It starts with low stand system tract of channel cut and fills on the top of the Kafr El Sheikh Formation (Fig. 4). 
Mahmoud, H. M. and AbouAshour, N. M. H.

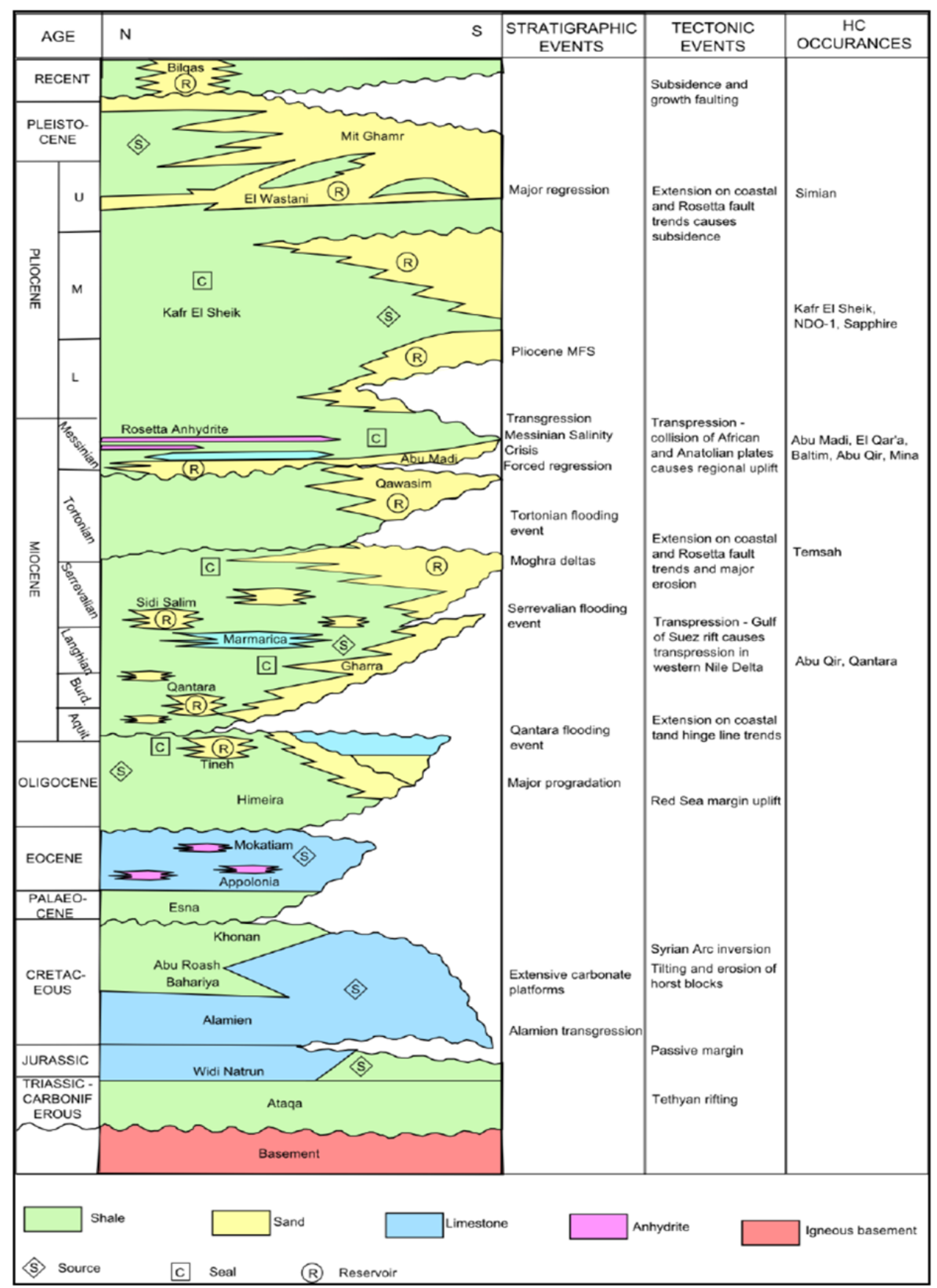

Fig. 4: Nile Delta tectonostraigraphy showing key stratigraphic and tectonic events and hydrocarbon occurrences.

\section{Structural settings}

The major structures within the concession area are the SW/NE trending Rosetta Fault and the ENEWSW trending Nile Delta offshore anticline (Fig. 2).

Simian gas field is a combination trap with a stratigraphic closure across the channel (via lateral channel pitchouts) and a structural dip-closure at its northern and southern margins (Fig. 5). The layers forming the seal above and below Simian reservoir of Wastani formation are Pliocene deep marine clay stone. The southern part of Simian field is made up of two main branches - the larger main channel to the east and the smaller central channel to the west separated by non-reservoir facies. These branches, especially the main channel, are generally more confined complexes with highly stacked/amalgamated channel sands to the south. To the north, the main channel becomes broader and less-confined. The central 
An intgrated approach for petrophysical evaluation

and main branches converge in the north; forming multiple sinuous channels that appear generally less confined and more bifurcated than the South.

Fig. 4: root mean square (RMS) amplitude map for Simian channel from top to base channel, showing the well locations and the different Parts/Regions of the field.

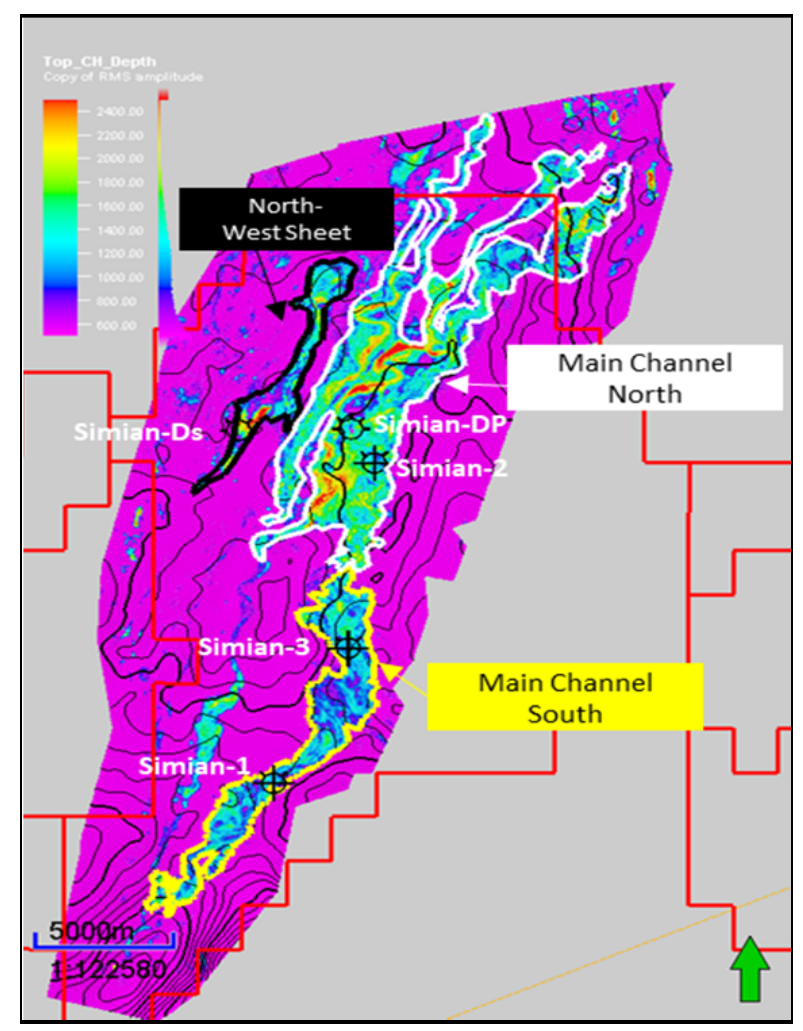

\section{Petrophysical Evaluation}

\section{Conventional log analysis}

Routine petrophysical evaluation is used to evaluate the data from the standard wire line log data, radiometric suite and resistivity suite according to work flow in Fig. 6 using Techlog Software.

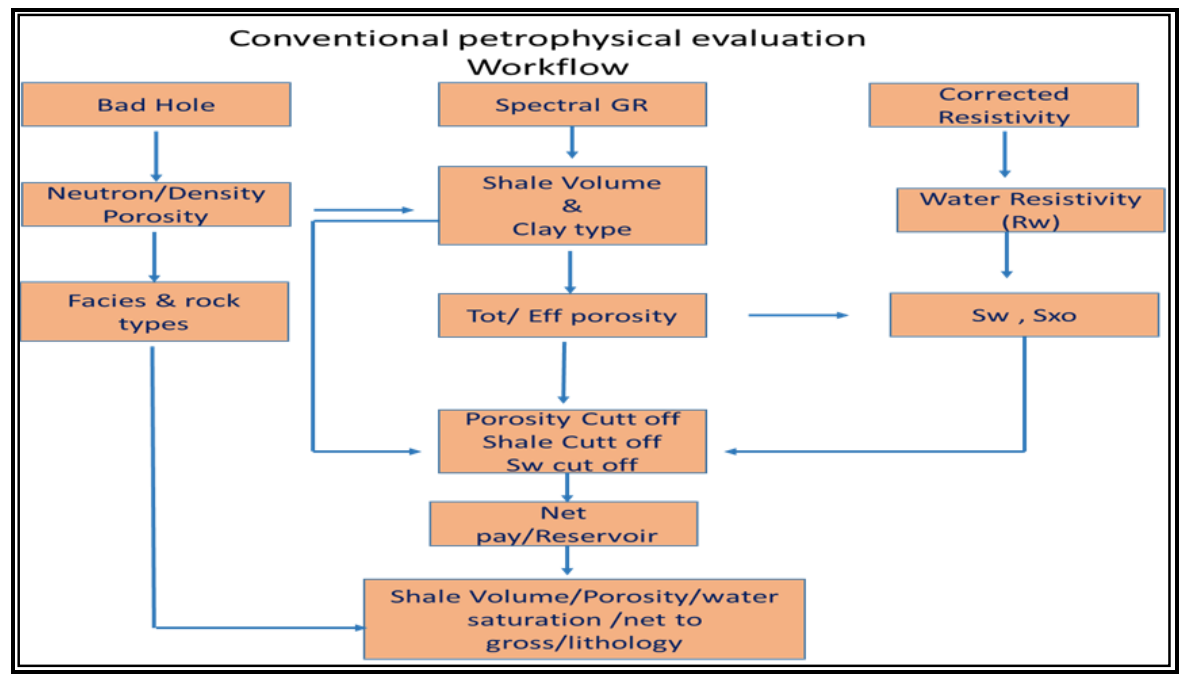

Fig. 5: Schematic Diagram Showing conventional petrophysical evaluation workflow.

Determination of Formation Temperature (FT) (Dresser Atlas, 1979)

$\mathrm{FT}=\mathrm{ST}+[((\mathrm{BHT}-\mathrm{ST}) / \mathrm{TD})] * \mathrm{FD}$

Where: (FT) is formation temperature, (ST) is surface temperature (BHT) is bottom hole temperature, (TD) is total depth and (FD) Formation depth (m). 
Mahmoud, H. M. and AbouAshour, N. M. H.

Determination of Shale Content (Vsh)

In this study the Shale volumes (Vsh) are calculated from GR log (Schlumberger, Log Interpretation, 1989).

$$
\text { VshGR }=[\text { GRlog }- \text { GRmin }] \text { / [GRmax }- \text { GRmin }] .
$$

Where:

VshGR: shale volume derived from gamma ray curve; GRlog: Gamma ray at the interest interval; GRmin: Gamma ray at the clean sand; GRmax: Gamma ray at the shale interval.

\section{Clay Minerals distribution and Identification}

The existence of shale in reservoir rock is, however, an extremely disturbing factor because it (a) Complicates the determination of gas -in-place, (b) considerably reduces the Permeability of the reservoir rock for gas production, and (c) significantly affects the reservoir characterization of shaly sand producing formations. Shale may be distributed in sandstone reservoirs in three possible forms: structure, laminated and dispersed clays.

So in this study potassium thorium (Th-K) cross plots is used for clay minerals identifications and Thomas Stieber cross plot for clay distribution within reservoirs and that was calibrated to X-ray diffraction analysis for core data.

Determination of Formation Porosity $(\phi)$

Determination of porosity from conventional tools was achieved through combining the neutron and density porosities:

$$
\begin{aligned}
& \Phi \mathrm{t}=(\Phi \mathrm{D}+\Phi \mathrm{N}) / 2 \\
& \Phi \text { eff }=\Phi \mathrm{T}-\mathrm{V} \text { clay } * \text { clay }
\end{aligned}
$$

\section{Permeability determination}

Permeability is calculated using Coates equation (5) (Schlumberger, Log Interpretation, 1989) considering that the calculated water saturation above free water level is Irreducible water saturation, keeping in mind that calculation of irreducible water saturation using conventional tools in shaly sand reservoirs like Simian channel is very critical with high uncertainty due to the effect of clay minerals as mentioned before

$$
\text { PERM }=k c * P H L e^{4} *\left(\frac{P H L t-P H L e * \text { Swirr }}{P H L e * \text { Swirr }}\right)^{2}
$$

Where

(Swirr) irreducible water saturation (Phie) effective porosity, (Phit) total porosity, (Kc) Permeability coefficient

\section{Determination of Fluid Saturations (Sw \& Sh)}

Determination of water saturation from conventional tools was achieved through Indonesian model (Schlumberger, Log Interpretation, 1989), considering $\mathrm{a}=1, \mathrm{~m}=1.713$ and $\mathrm{n}=1.86$ calibrated to core data:-

$$
\frac{1}{\sqrt{R t}}=\left(\sqrt{\frac{\emptyset^{m}}{a * R w}}+\frac{V c l^{\left(1-\frac{V c l}{2}\right)}}{\sqrt{R c l}}\right) * S w^{\frac{n}{2}}
$$

Where: 
An intgrated approach for petrophysical evaluation

(m) Cementation Factor, (n) Saturation exponent, (a)Tortuosity Factor, (Vcl) Wet Clay Volume, $\left(\mathrm{S}_{\mathrm{w}}\right)$ Effective water saturation, (Rw) Formation water resistivity (Rt )Input Resistivity Curve, (Rcl) Resistivity of the clay.

The hydrocarbon saturations were calculated as follows:-

$\mathrm{S}_{\mathrm{h}}=1-\mathrm{S}_{\mathrm{w}}$

For this study there are two cutoff values, one for reservoir (reservoir flag) where volume of shale (Vsh) is $<60 \%$ and effective porosity (PHIE) is $>10 \%$, and the other one is for pay (pay flag) by adding effective water saturation SWE to be less than $70 \%$, to provide convention tools based results .

\section{Advanced log analysis tools}

\section{log analysis using CMR tool}

Advanced logging tools available in this study are combinable magnetic resonance (CMR) and Formation micro imager (FMI) as they are playing an important role in lithological and petrophysical evaluation of the unconventional reservoirs that can't be detected on the conventional logging tools (workflow in figure 7). In the present study the unconventional reservoirs are represented by thin bedded intervals which exist in Simian reservoir as it is channelized system which combine a plenty of sand facies includes coarse grain sandstone and very fine grain sandstone intercalated with shale layers. The determination of porosity from CMR tool based on new gas equation (8) derived recently by Freedman (1998) and will be referred to as the Density-Magnetic Resonance (DMR) method as it combines total porosity from the CMR* combinable Magnetic Resonance tool (TCMR) and density log-derived porosity (DPHI) to get gas-corrected total formation porosity as follow.

$$
\text { DMRP }=\text { PHID } x\left(1-\frac{\text { HIg } x \text { Pgas }}{\text { HIf }}+\left(\frac{\frac{\lambda+\text { TCMR }}{H I F}}{\left(1-\frac{\text { HIg } \times \text { Pgas }}{\text { HIf }}\right)+\lambda}\right)\right.
$$

Where:

$\mathrm{DMRP}=$ Total porosity corrected to gas effect.

PHID $=(\rho m a-\rho b) /(\rho m a-\rho f) v / v$.

$\lambda=(\rho f-D G) /(\rho m a-\rho f)$.

Pgas $=1-\mathrm{e}(-\mathrm{W} / \mathrm{T} 1 \mathrm{~g})$.

Pgas: Polarization of gas, $\mathrm{W}$ is wait time \& T1g is gas longitudinal relaxation time at reservoir conditions gas (polarization time)

HIf: Hydrogen Index of water in flushed zone $=1$

DG: Density of gas at reservoir conditions $(\mathrm{g} / \mathrm{cm} 3)$ and it is determined from MDT gradient.

\section{Water saturation from CMR tool}

$\mathrm{SWE}=$ effective water saturation (capillary water saturation) $=\mathrm{Cw} / \mathrm{PhiE}$

$\mathrm{As} \mathrm{Cw}$ is the volume of capillary water $=\mathrm{CBP} 3+\mathrm{CBP} 4$

Where:

CBP3: CMR Bin porosity from $3 \mathrm{msec}$ to $10 \mathrm{msec}$

CBP4: CMR Bin porosity from $10 \mathrm{msec}$ to $33 \mathrm{msec}$

The hydrocarbon saturations and movable $\left(\mathrm{S}_{\mathrm{hm}}\right)$ and residual hydrocarbons $(\mathrm{Shr})$ were determined as follows

$\mathrm{S}_{\mathrm{h}}=1-\mathrm{S}_{\mathrm{w}}, \mathrm{S}_{\mathrm{hr}}=1-\mathrm{S}_{\mathrm{xo}}, \mathrm{S}_{\mathrm{hm}}=\mathrm{S}_{\mathrm{h}}-\mathrm{S}_{\mathrm{hr}}$ 
Mahmoud, H. M. and AbouAshour, N. M. H.

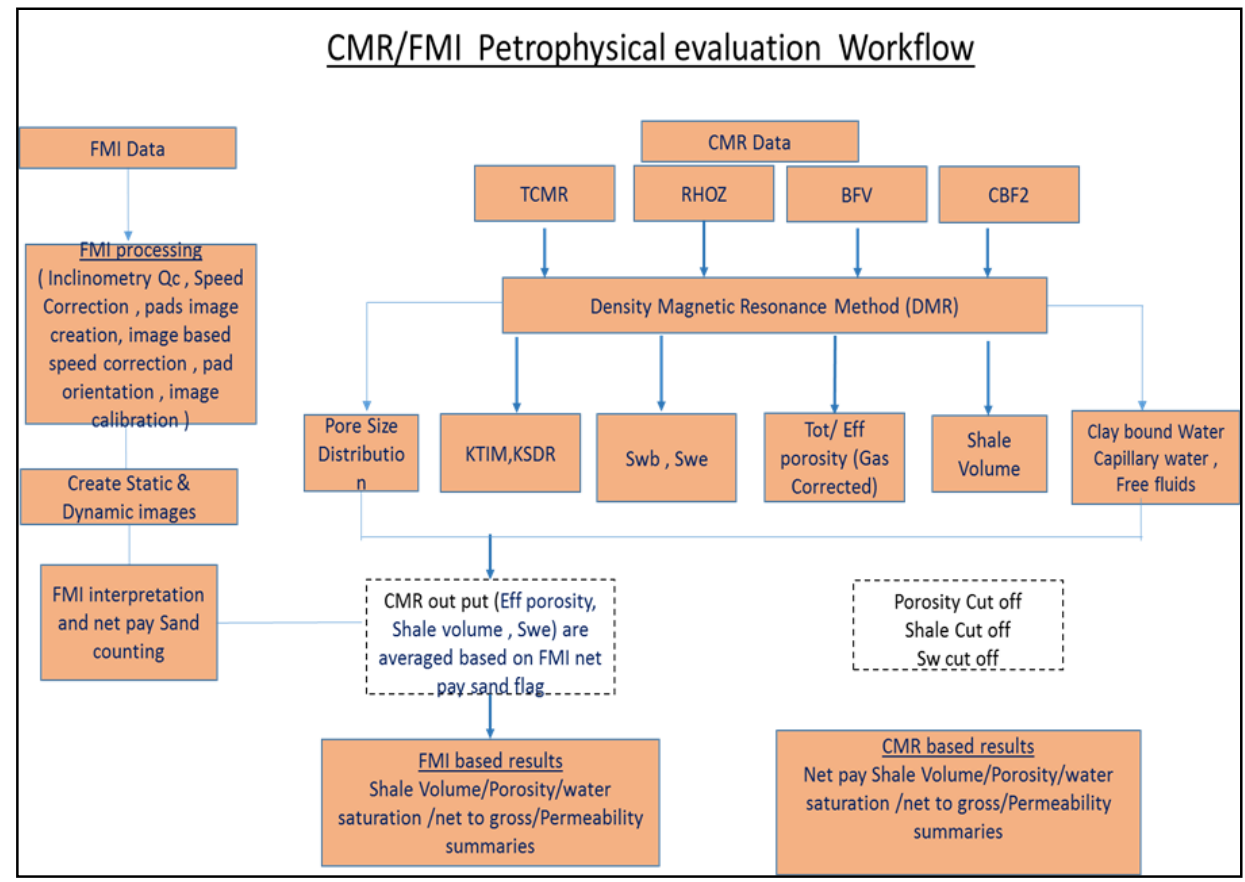

Fig. 6: Schematic

Diagram Showing

Advanced

petrophysical

evaluation workflow.

\section{Permeability determination from CMR}

The NMR data is used extensively to estimate permeability. This is because there is a direct correlation between permeability and the following parameters

Surface area/Pore volume ratio(S/V)

Pore throat diameter and hence pore size Porosity

Permeability is calculated based on Timur- Coates model (George R. Coates, Lizhi Xiao, and Prammer, 1999).

\section{Timur-Coates model:}

$$
\mathrm{KTC}=\mathrm{a} . \phi 4(\mathrm{FFV} / \mathrm{BVF}) 2
$$

Where:

Timur-Coates permeability (KTC) md, Porosity $(\phi)$ v/v, Free Fluid Volume (FFV) v/v, bound Fluid Volume $(\mathrm{BFV}) \mathrm{v} / \mathrm{v}$. a is a constant.

After that, reservoir flag, pay flag, average effective porosity, average effective water saturation and average volume of shale are estimated providing CMR based results.

\section{Log analysis using FMI tool.}

The main objectives of FMI interpretation are:

The detailed evaluation of thin bedded pay over interlaminated shale sand sections (high resistive (white color) means gas sand or carbonates, low resistive (dark color) means clay or water sand.

Sand count estimation above free water level for accurate estimation of net to gross sand within Simian channel and based on these net sand effective porosity, water saturation and volume of shale from CMR tool are averaged to provide FMI based results.

\section{Integrated study and discussion}

Both the conventional wireline tools and CMR/FMI evaluation are producing a complete set of selfconsistent evaluation results. 
An intgrated approach for petrophysical evaluation

Using conventional resistivity data, quantification of the hydrocarbon reserve potential of such highly laminated shaly sand reservoir is hard and that confirmed through Thomas Stieber cross plot for Simian channel (Fig. 8A) reflecting the distribution of shale within Simian channel as it mainly laminated shale with few percentage of dispersed shales. Since the data is dominated by the conductivity of the shale laminae or clay minerals which confirmed by Potassium -Thorium cross plot (Fig. 8B) for Simian channel showing the presence of high percentage of smectite / illite in mixed layer in addition to mica and glauconite which reduce resistivity reading and masked some pay intervals specially in such thin laminated reservoir. Conventional logging tools have a lower resolution compared to CMR which has 6 inc vertical resolution and FMI which has 0.2 inc vertical resolution which means that petrophysical evaluation of thin bedded intervals will be very hard using conventional tools only comparing to CMR tool or FMI and that can be represented by comparing CMR/FMI results with conventional tools results (Fig. 14).

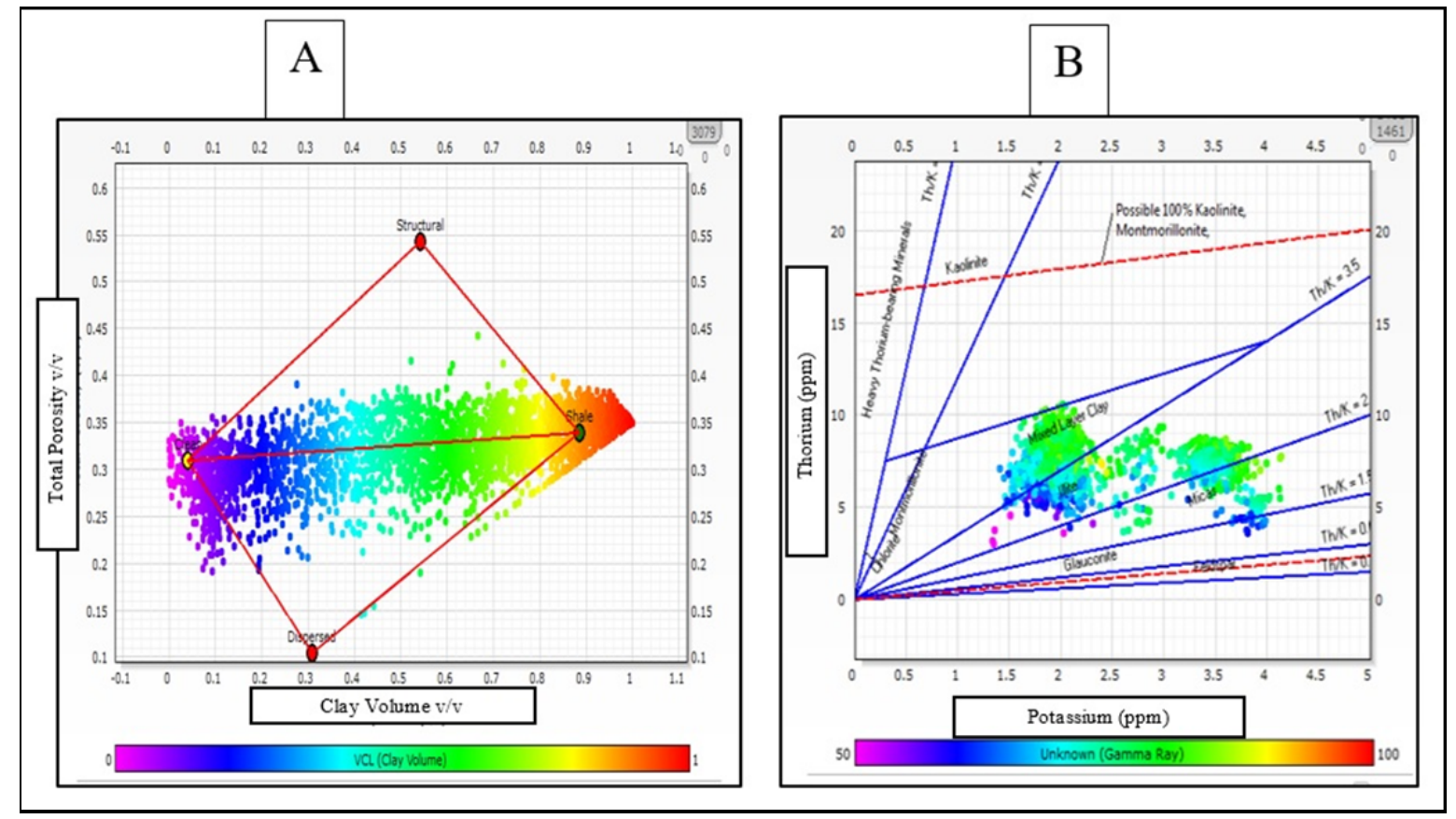

Fig. 7: A: Thomas Stieber cross plot for Simian channel. B) Th-K cross plot for clay intervals in Simianchannel.

As effective porosity from conventional tools is lower than CMR tool by 3-5 pu except Simian-3 well which show higher conventional effective porosity compared to CMR effective porosity due to highly thin bedded intervals in Simian-3 well which was not recognized on conventional tools as net pay thickness in Simian -3 from conventional tools is $41 \mathrm{~m}$ while from CMR it is $80 \mathrm{~m}$ and FMI is $82 \mathrm{~m}$. Net pay thickness and net to gross to free water level shows a high difference between conventional tools and CMR/FMI in Simian-1,2 and 3 reflecting highly thin bedded intervals in these wells which couldn't capture on conventional tools and difference became lower in Simian Dp and Simian Ds wells reflecting lowest thin bedded intervals. All of these parameters are summarized in hydrocarbon pore thickness figure. This difference doesn't mean to neglect conventional results and use only CMR/FMI results as each one has a weak point as Conventional logging tools has a lower resolution, on the other hand CMR tool's has a shorter depth of investigation 1.5 inc compared to which can be reached by some of conventional tools (50 inc) which means that if we have rugist hole (Washout) CMR results will have high uncertainty and conventional tools will help in such case in addition to density tool is used to correct CMR porosity for gas effect (DMRP technique), so conventional logging data should be combine with data from CMR and FMI tools to get a comprehensive figure and results.

There are three indicators of net pay sand, the first one is sand intervals which defined on FMI tool, second is the sand defined by CMR tool above the free water contact and the third one will be pay flag which defined by conventional tools. These were combined in the following manner producing three cases 
Mahmoud, H. M. and AbouAshour, N. M. H.

for net pay sand. The values of net pay sand were summed and three flags produced according to the resultant value. If all the three indicators showed net pay sand flag was produced, this is will be considered as Case 1. If at least two out of the three indicators showed net pay sand, this will be considered as Case 2. If at least one net pay sand flag showed, this will be considered as Case 3. In front of each case we will have an average of effective porosity that calculated based on a combination of CMR porosity and density $\log$ (DMR technique) Vcl will be calculated directly from CMR as discussed before; effective water saturation will be calculated also from CMR also.

\section{Results}

It is clear that Comprehensive petrophysical evaluation carried out for five wells in Simian field (Fig. $9,10,11,12,13$ ) using the work flow that discussed above is carried out for 5 Simian wells to have three different petrophysical parameters for the three cases check table 3 and figure 15 and will provide three different reserve numbers. As Case 1 will be an extremely conservative case and is an underestimation of the reserves in the reservoir. The net is only considered present if all the indicators are positive. Actually in this case we will have lowest N/G and net pay sand but on the other side we will have the highest porosity and lowest water saturation as we will pick the high quality sands or reservoirs.

It is also evident that Case 2 is slightly more optimistic than the Case 1 as the net sand is identified by two indicators being positive. In Case 3 net sand will be defined by any of the three methods, Conventional open hole logs, CMR or FMI indicating the presence of a sand, in this case we will have highest N/G, Net sand but on the other side we will have the lowest porosity and highest water saturation as we will recognize low quality and high quality reservoirs.

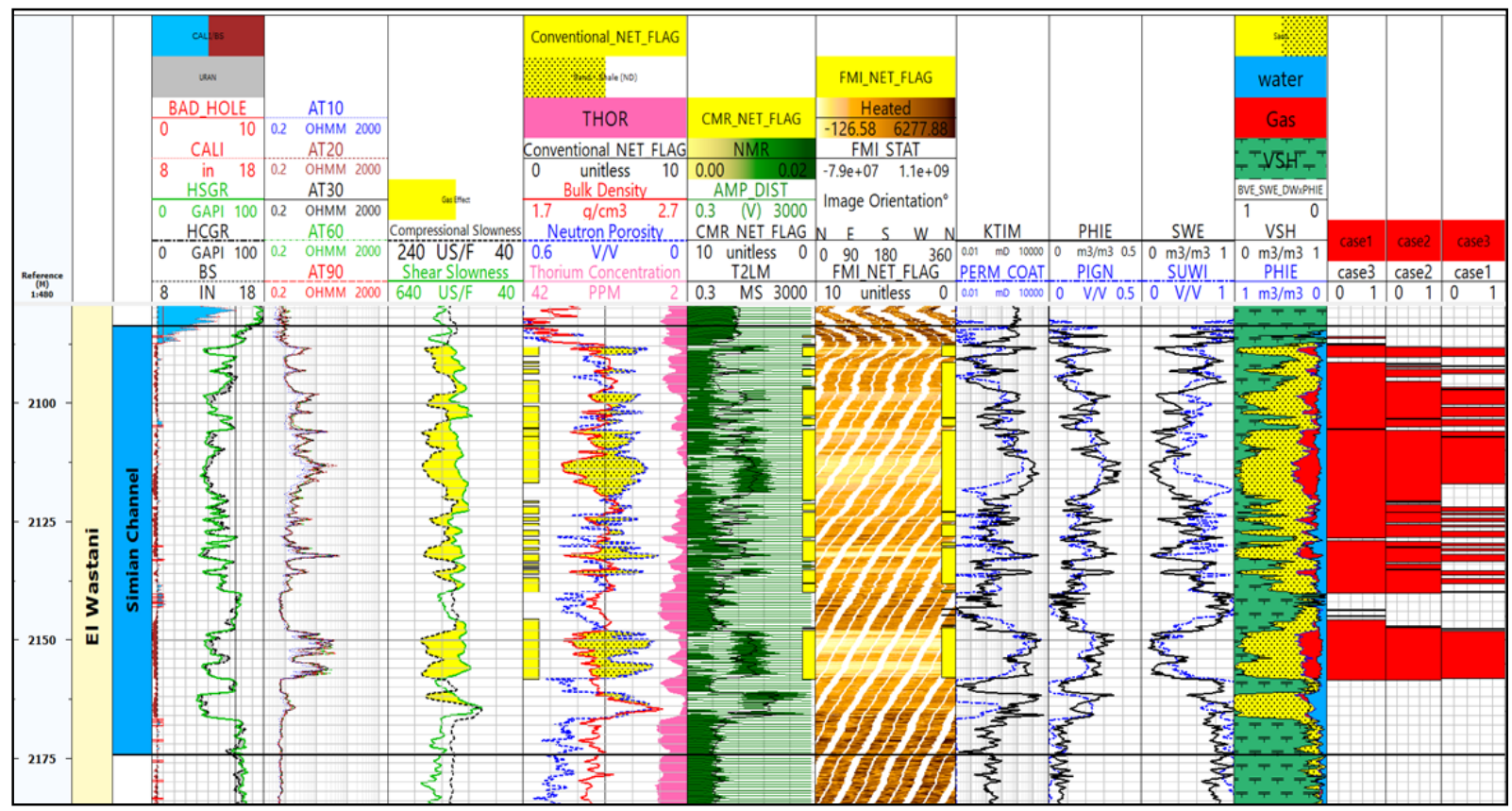

Fig. 8: Combination of Results and net pay Probability for Simian-1 Well (effective porosity (PIGN), water saturation (SUWI), Permeability (PERM_COAT) calculated from conventional tools are in blue color, while (effective porosity (PHIE), water saturation (SWE), Permeability (KTIM) calculated from CMR in black color. 
An intgrated approach for petrophysical evaluation

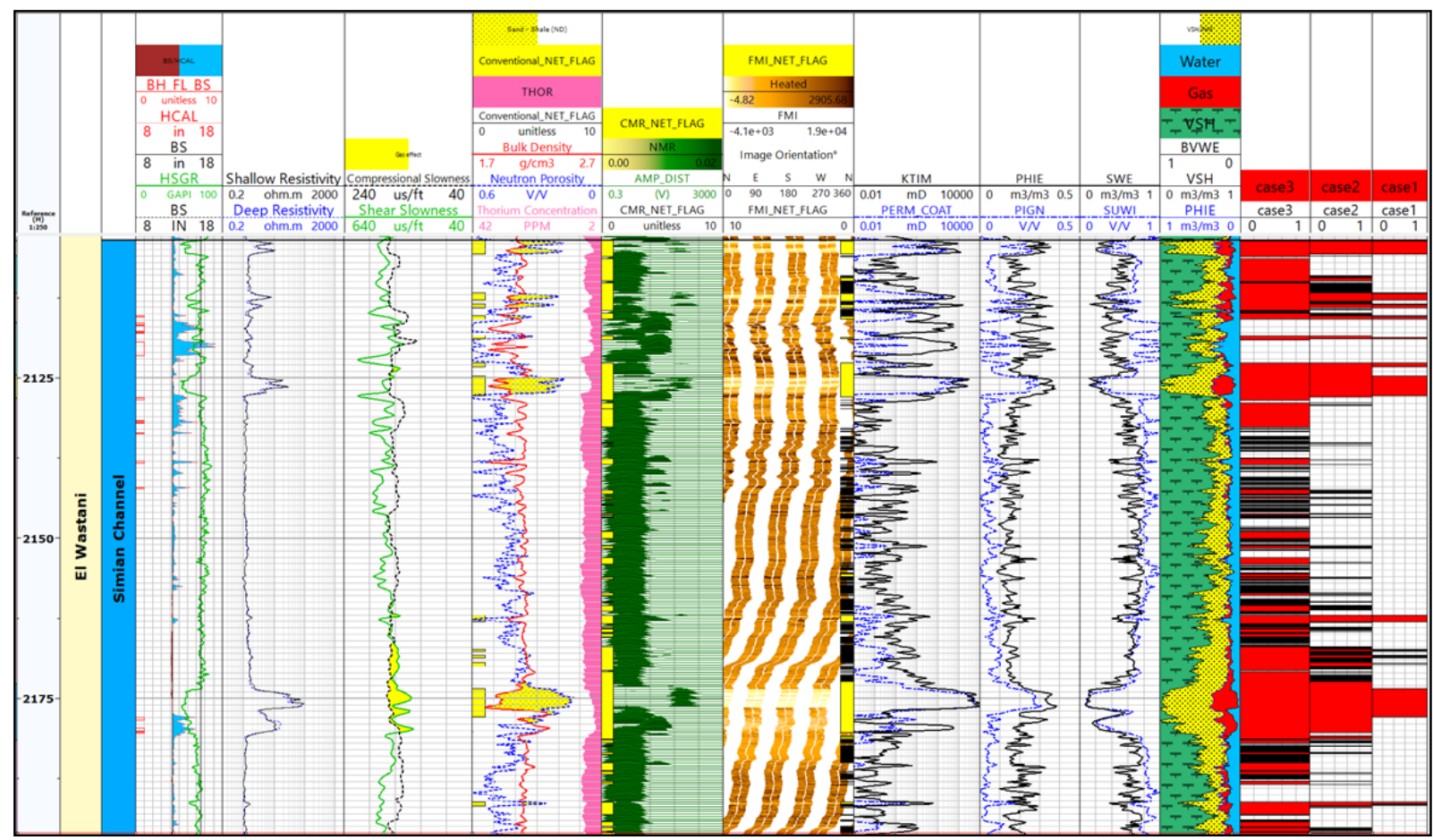

Fig. 9: Combination of Results and net pay Probability for Simian-2 Well.

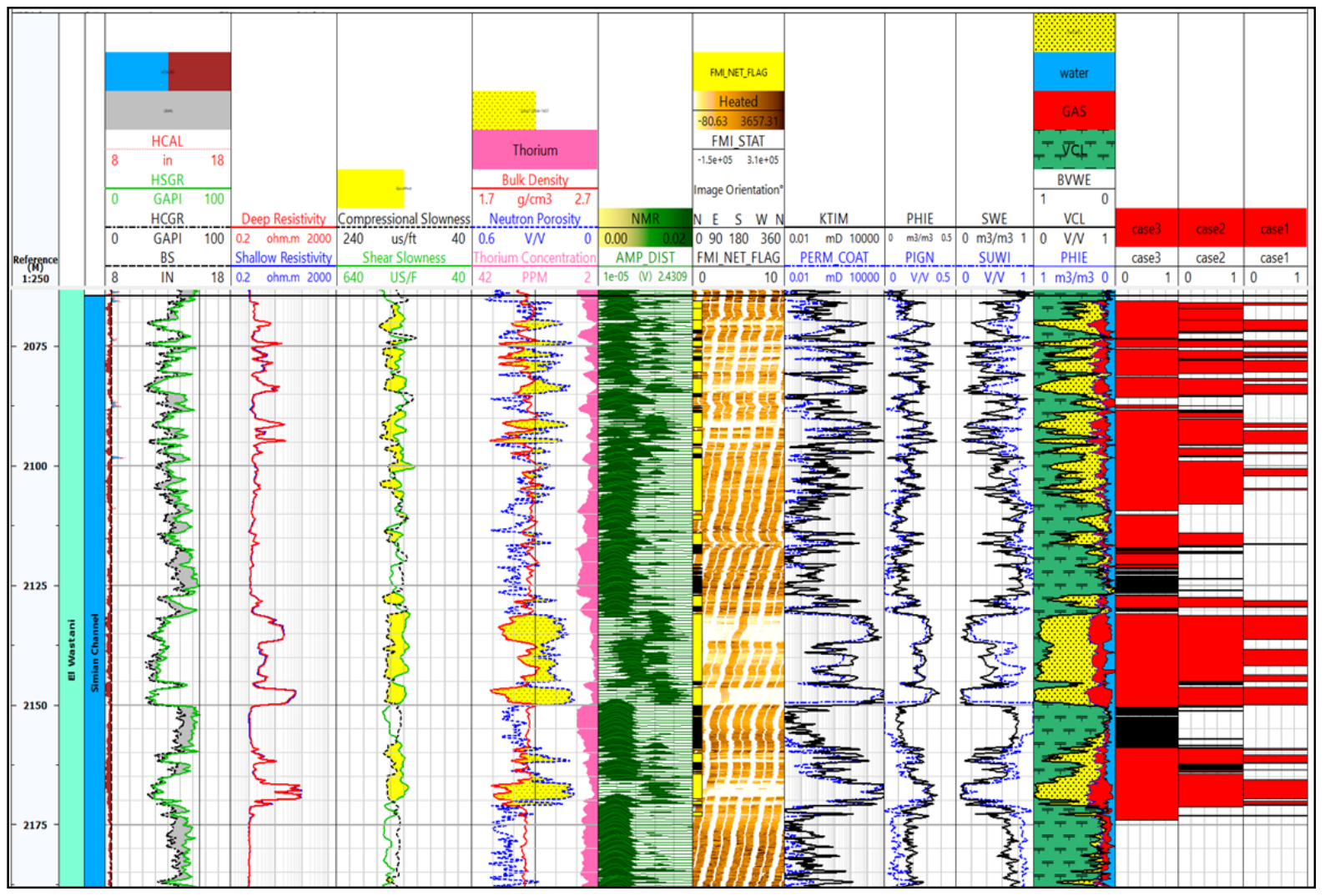

Fig. 10: ccombination of Results and net pay Probability for Simian-3 Well. 
Mahmoud, H. M. and AbouAshour, N. M. H.

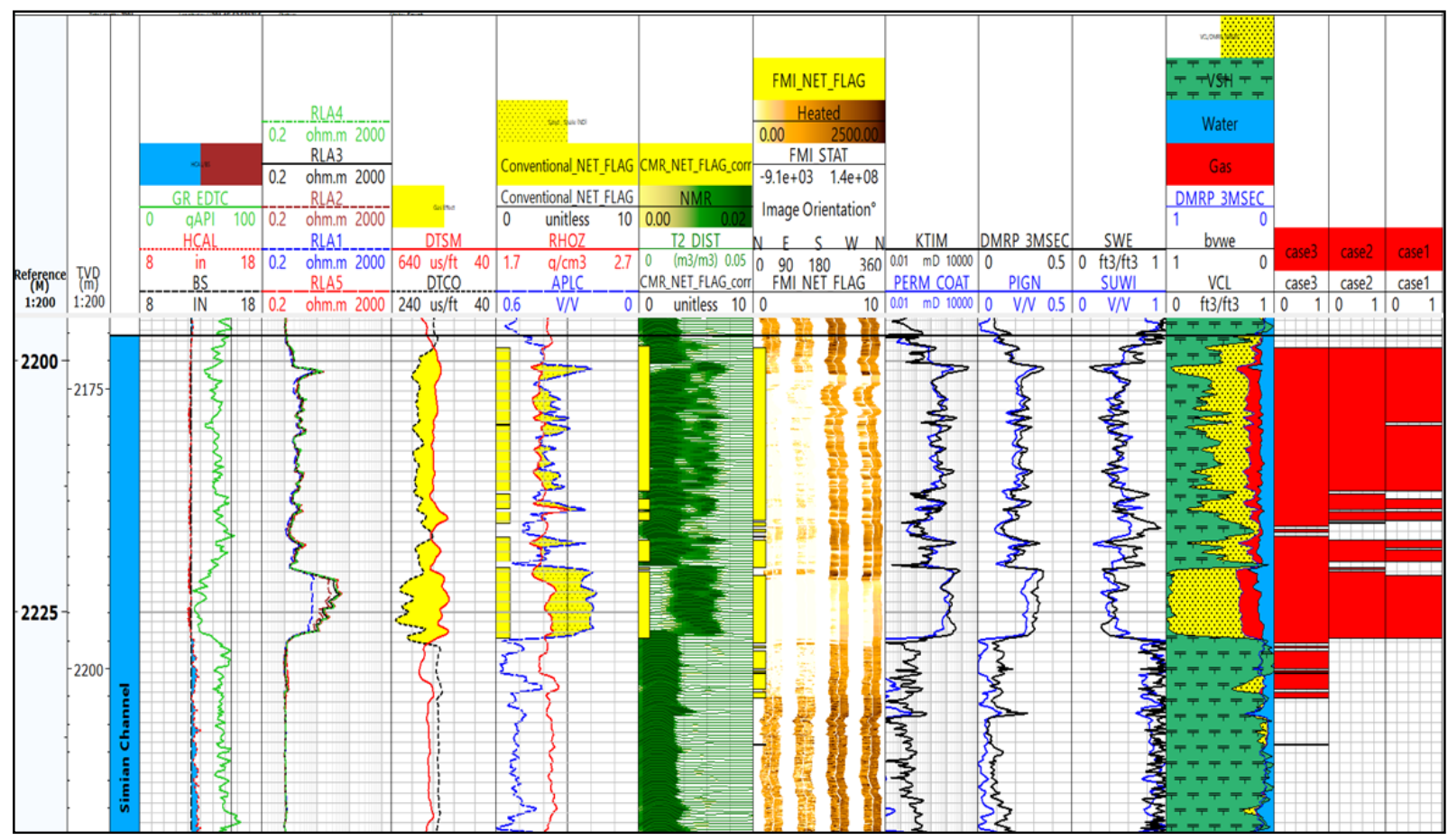

Fig. 11: Combination of Results and net pay Probability for Simian-Ds Well

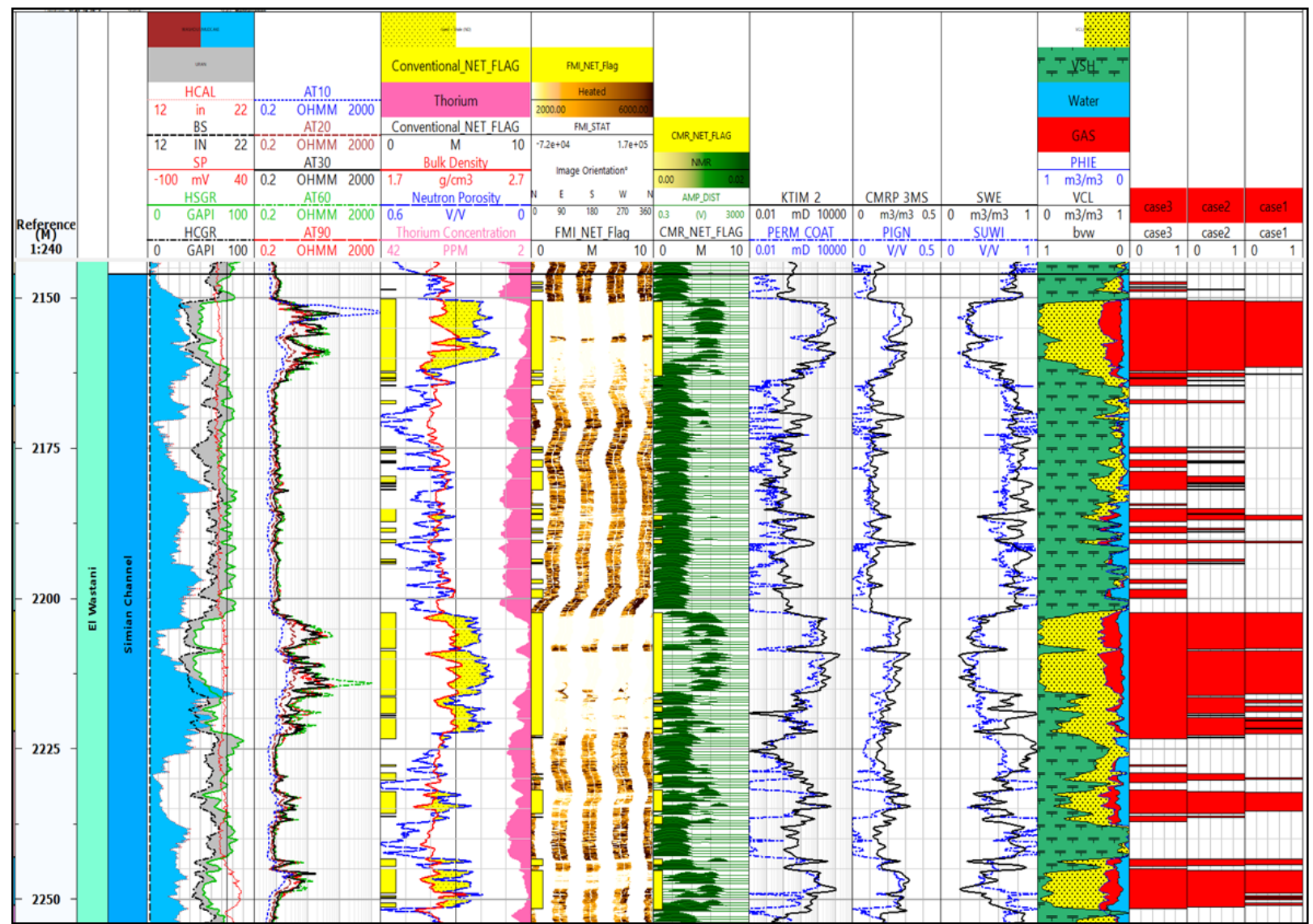

Fig. 12: Combination of Results and net pay Probability for Simian-Dp Well. 
Table 1: petrophysical parameters in Simian field calculated based conventional tools (Conv), CMR and FMI.

\begin{tabular}{|c|c|c|c|c|c|c|c|c|c|c|c|c|c|c|c|c|c|c|}
\hline \multicolumn{17}{|c|}{ Conventional \& CMR Analysis } & \multicolumn{2}{|c|}{ FMI Analysis } \\
\hline \multirow[t]{2}{*}{ Well } & \multirow[t]{2}{*}{$\begin{array}{l}\text { Top } \\
\text { (m) }\end{array}$} & \multirow[t]{2}{*}{$\begin{array}{c}\text { Bottom } \\
\text { (m) }\end{array}$} & \multirow{2}{*}{$\begin{array}{c}\text { Free } \\
\text { Water } \\
\text { level } \\
(\text { FWL })\end{array}$} & \multirow{2}{*}{$\begin{array}{l}\text { Gross } \\
\text { Thickness } \\
\text { TO FWL } \\
\text { (m) }\end{array}$} & \multicolumn{2}{|c|}{$\begin{array}{l}\text { Net Thickness } \\
\quad(\mathrm{m})\end{array}$} & \multicolumn{2}{|c|}{$\begin{array}{l}\text { Net to Gross } \\
\text { Thickness }\end{array}$} & \multicolumn{2}{|c|}{$\begin{array}{l}\text { HCPOR-TH } \\
\text { (m) }\end{array}$} & \multicolumn{2}{|c|}{$\begin{array}{l}\text { Effective } \\
\text { Porosity } \\
\text { V/v }\end{array}$} & \multicolumn{2}{|c|}{$\begin{array}{c}\text { Effective Water } \\
\text { Saturation } \\
\text { v/v }\end{array}$} & \multicolumn{2}{|c|}{$\begin{array}{l}\text { Permeability } \\
\quad(\mathrm{mD})\end{array}$} & \multirow[t]{2}{*}{$\begin{array}{c}\text { Net } \\
\text { Thickness } \\
(\mathrm{m})\end{array}$} & \multirow[t]{2}{*}{$\begin{array}{l}\text { Net to } \\
\text { Gross } \\
\text { Thickness }\end{array}$} \\
\hline & & & & & Conv & CMR & Conv & CMR & Conv & CMR & Conv & CMR & Conv & CMR & Conv & CMR & & \\
\hline Simian-1 & 2084 & 2174 & 2161 & 77.4 & 47.10 & 53.1 & 0.61 & 0.69 & 5.19 & 8.7 & 0.2 & 0.24 & 0.48 & 0.30 & 96 & 268 & 67 & 0.87 \\
\hline Simian-2 & 2104 & 2198 & 2198 & 94.5 & 15.60 & 55.25 & 0.17 & 0.58 & 1.95 & 7.4 & 0.2 & 0.23 & 0.37 & 0.42 & 394 & 424 & 65.5 & 0.69 \\
\hline Simian-3 & 2064 & 2224 & 2185 & 120.1 & 41.25 & 80.5 & 0.34 & 0.67 & 6.03 & 11.9 & 0.3 & 0.24 & 0.42 & 0.37 & 1255 & 1317 & 82 & 0.68 \\
\hline $\begin{array}{c}\text { Simian- } \\
\text { Dp }\end{array}$ & 2106 & 2222 & 2200 & 94.2 & 47.62 & 51.11 & 0.51 & 0.54 & 5.21 & 7.2 & 0.2 & 0.25 & 0.43 & 0.44 & 71 & 177 & 52.3 & 0.56 \\
\hline $\begin{array}{c}\text { Simian- } \\
\text { Ds }\end{array}$ & 2170 & 2244 & 2208 & 37.8 & 21.00 & 21.36 & 0.56 & 0.57 & 2.42 & 2.9 & 0.2 & 0.26 & 0.47 & 0.47 & 50 & 121 & 28 & 0.74 \\
\hline
\end{tabular}

Table 2 comprehensive petrophysical parameters in Simian field calculated based on three cases of net sand

\begin{tabular}{|c|c|c|c|c|c|c|c|c|c|c|c|c|c|}
\hline $\begin{array}{l}\text { Well } \\
\text { Name }\end{array}$ & $\begin{array}{l}\text { Flag } \\
\text { Name }\end{array}$ & $\begin{array}{l}\text { Top } \\
\text { (m) }\end{array}$ & $\begin{array}{l}\text { Botto } \\
\mathrm{m}(\mathrm{m})\end{array}$ & $\begin{array}{l}\text { Gross } \\
\text { Thickness } \\
(\mathrm{m})\end{array}$ & FWL & $\begin{array}{l}\text { Gross } \\
\text { Thickness to } \\
\text { FWL }(\mathrm{m})\end{array}$ & $\begin{array}{l}\text { Net pay } \\
\text { thickness } \\
(\mathrm{m})\end{array}$ & $\begin{array}{l}\text { Net to Gross } \\
\text { Thickness- } \\
\text { FWL }\end{array}$ & $\begin{array}{l}\text { Effective } \\
\text { Water } \\
\text { Saturation }\end{array}$ & $\begin{array}{c}\text { shale Volume } \\
\text { v/v" }\end{array}$ & $\begin{array}{c}\text { Effective } \\
\text { Porosity } \\
\mathrm{v} / \mathrm{v}^{\prime \prime}\end{array}$ & $\begin{array}{l}\text { HCPOR-TH } \\
\text { (m)" }\end{array}$ & $\begin{array}{l}\text { Permeability } \\
\text { (mD) }\end{array}$ \\
\hline \multirow{3}{*}{$\begin{array}{c}\text { Simian- } \\
1\end{array}$} & Case1 & 2084 & 2174 & 90 & 2161 & 77.4 & 45.2 & 0.58 & 0.27 & 0.18 & 0.25 & 8.15 & 335 \\
\hline & Case2 & 2084 & 2174 & 90 & 2161 & 77.4 & 56.2 & 0.73 & 0.32 & 0.22 & 0.22 & 8.63 & 246 \\
\hline & Case3 & 2084 & 2174 & 90 & 2161 & 77.4 & 64.0 & 0.83 & 0.34 & 0.26 & 0.21 & 8.98 & 217 \\
\hline \multirow{3}{*}{$\begin{array}{c}\text { Simian- } \\
2\end{array}$} & Case1 & 2104 & 2198 & 95 & 2198 & 94.5 & 14.2 & 0.15 & 0.30 & 0.21 & 0.28 & 2.75 & 1792 \\
\hline & Case2 & 2104 & 2198 & 95 & 2198 & 94.5 & 25.3 & 0.27 & 0.39 & 0.29 & 0.24 & 3.70 & 1025 \\
\hline & Case3 & 2104 & 2198 & 95 & 2198 & 94.5 & 56.6 & 0.60 & 0.51 & 0.43 & 0.21 & 5.69 & 460 \\
\hline \multirow{3}{*}{$\begin{array}{c}\text { Simian- } \\
3\end{array}$} & Case1 & 2064 & 2224 & 159 & 2185 & 120.1 & 39.5 & 0.33 & 0.27 & 0.14 & 0.27 & 7.70 & 2059 \\
\hline & Case2 & 2064 & 2224 & 159 & 2185 & 120.1 & $\begin{array}{l}68.1 \\
\end{array}$ & 0.57 & 0.35 & 0.20 & 0.24 & 10.65 & 1499 \\
\hline & Case3 & 2064 & 2224 & 159 & 2185 & 120.1 & 88.5 & 0.74 & 0.39 & 0.27 & 0.22 & 12.09 & 1165 \\
\hline \multirow{3}{*}{$\begin{array}{l}\text { Simian- } \\
\text { DP }\end{array}$} & Case1 & 2106 & 2222 & 116 & 2200 & 94.2 & 34.8 & 0.37 & 0.39 & 0.16 & 0.26 & 5.50 & 235 \\
\hline & Case2 & 2106 & 2222 & 116 & 2200 & 94.2 & 45.6 & 0.48 & 0.43 & 0.24 & 0.23 & 6.03 & 182 \\
\hline & Case3 & 2106 & 2222 & 116 & 2200 & 94.2 & 58.1 & 0.62 & 0.48 & 0.33 & 0.21 & 6.46 & 144 \\
\hline \multirow{2}{*}{$\begin{array}{l}\text { Simian- } \\
\text { DS }\end{array}$} & Case1 & 2170 & 2244 & 74 & 2208 & 37.8 & 20.7 & 0.55 & 0.47 & 0.29 & 0.26 & 2.83 & 126 \\
\hline & Case2 & 2170 & 2244 & 74 & 2208 & 37.8 & 23.1 & 0.61 & 0.48 & 0.31 & 0.26 & 3.07 & 125 \\
\hline
\end{tabular}


Mahmoud, H. M. and AbouAshour, N. M. H.
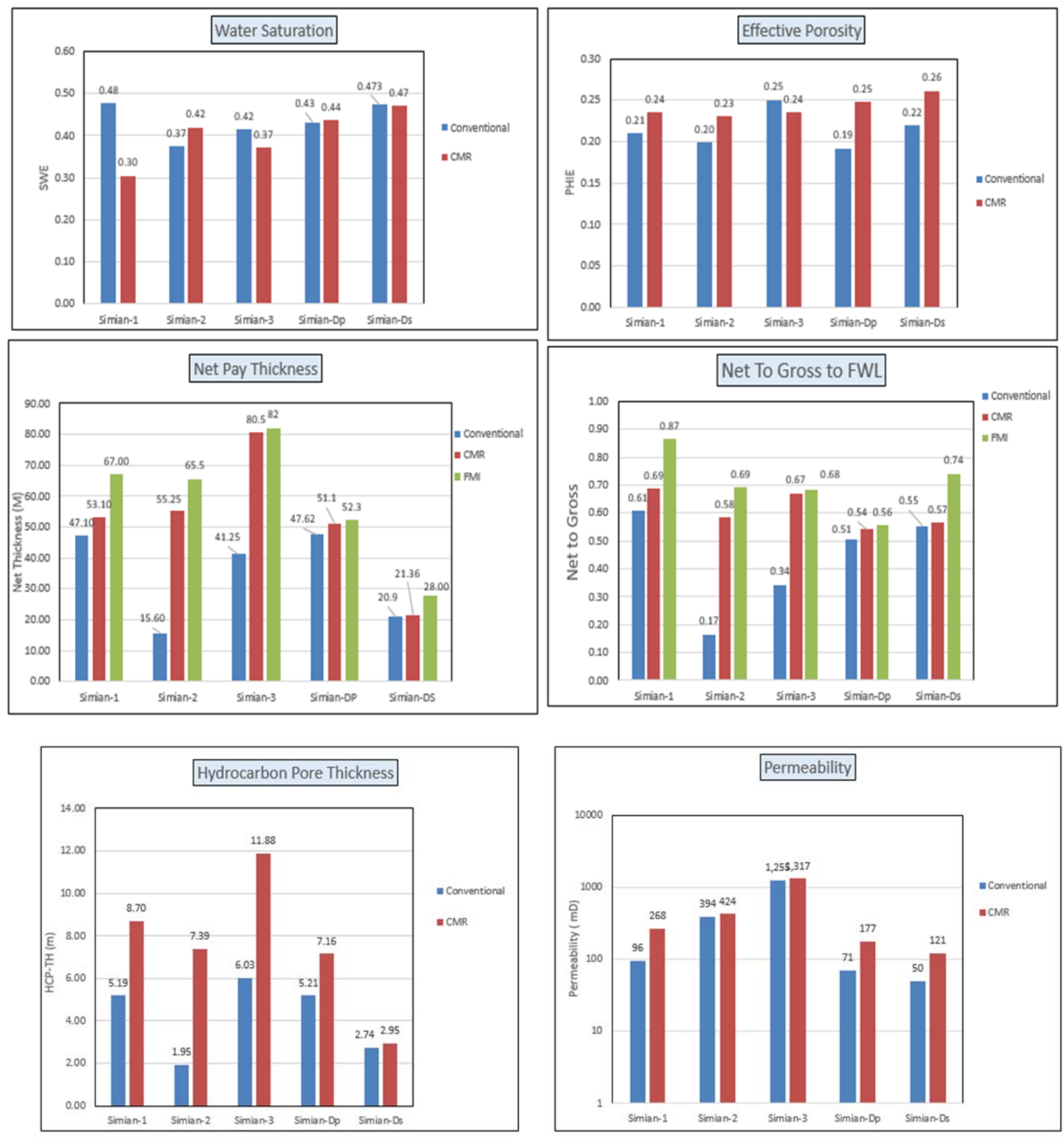

Fig. 13: Comparison between petrophysical results from conventional tools, CMR and FMI for water saturation, effective porosity, net pay thickness, net to gross to free water level, hydrocarbon pore thickness and permeability.

\section{SUMMARY AND CONCLUSION}

Simian gas field is a combination trap with a stratigraphic closure across the channel, Simian-1, Simian-2 and Simian-3 wells confirming that Simian channel is highly thin bedded gas sand reservoir with high shale content checked by using Thomas Stieber crossplot and potassium thorium cross plots as most clay minerals are Smectite, illite and moderate percentage of mica and shale is distributed within reservoir as laminated shale and in some intervals and that leads to miss pay intervals if conventional tools are only used. FMI/CMR enhanced the petrophysical evaluation and defined thin bedded intervals that couldn't be defined by conventional tools; however conventional tools are used to correct CMR porosity for gas effect and to define fluids contacts. Three net sands are produced by conventional tools, CMR and FMI providing three cases for petrophysical parameters to decrease the uncertainty of reserve calculation and provide a comprehensive figure about the reservoir covering all the possible facies quality in such turbidity system. It is recommended to use this integrated approach for such shaly sand reservoir especially for channelized reservoirs in the Nile Delta to avoid missing significant gas volumes within thinly bedded sand, and quantify the uncertainty associated with the computation of gas reserves within these sands. 
An intgrated approach for petrophysical evaluation
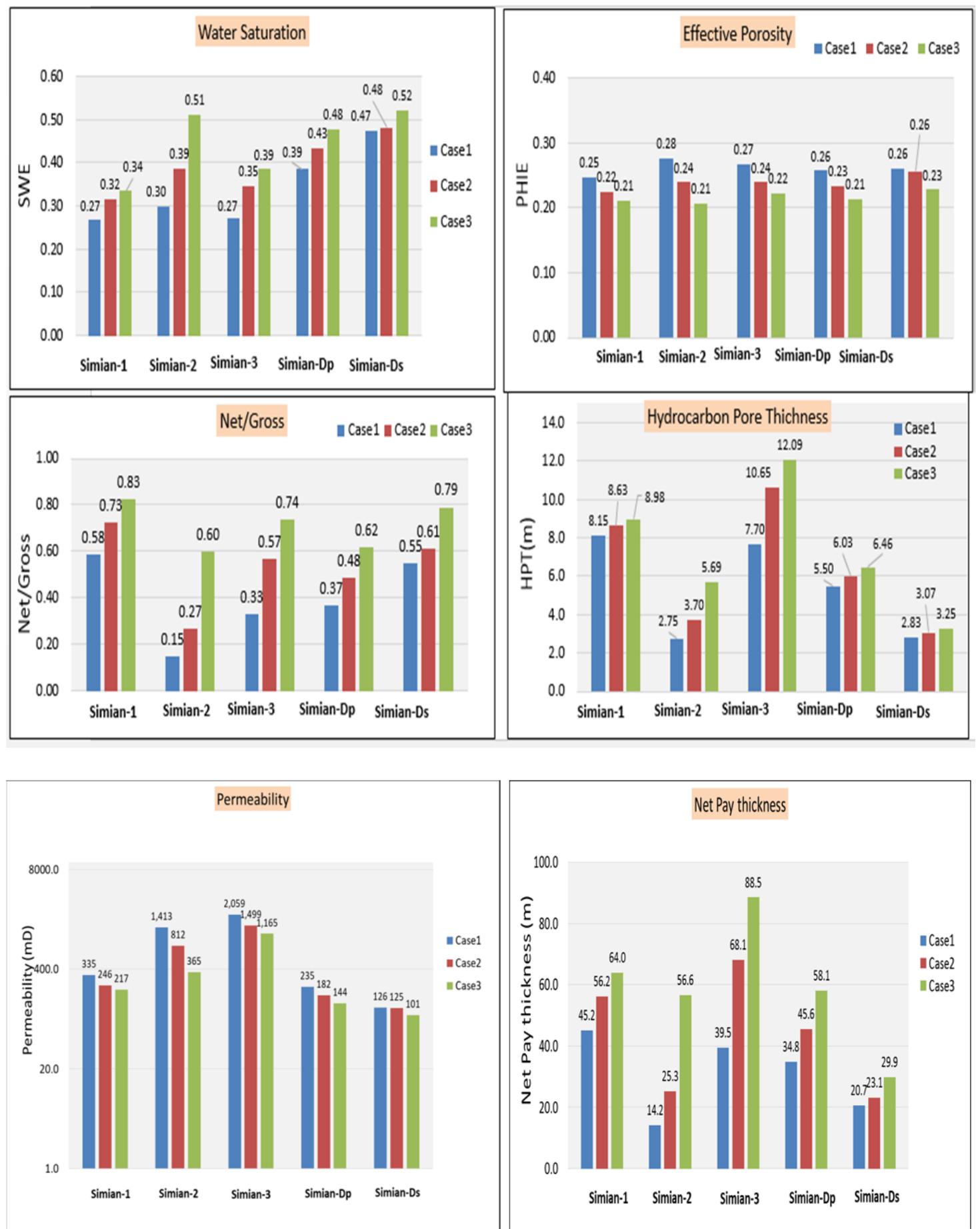

Fig. 14: Petrophysical parameters distribution in Simian field calculated based on three cases of net sand.

\section{REFERENCES}

Abdel Aal, A., El Barkooky, A. N., Gerrits, M., Meyer, H., Schwander, M. and Zaki, H., (2001): Tectonic evolution of the eastern Mediterranean basin and its significance for the hydrocarbon prospectivity of the Nile Delta ultra-deepwater area, Leading Edge, 1086-1102.

Barber, P. M., (1981): Messinian subaerial erosion of the proto Nile Delta. Mar. Geol., 44, 253-272

Coates, G. R., Xiao, L. Z and Prammer, M. G. (1999): NMR logging principles \& applications. Halliburton, 234.

Dolson, J. V., P. J. Boucher, J. Siok and P. D. Heppard, (2005): Key challenges to realizing full potential in an emerging gas giant province: Nile Delta/Mediterranean offshore, deepwater, Egypt: Geol. Soc., London, Petroleum Geol. Conf. series, 6, 607 - 624.

Dresser Atlas, (1979): Log Interpretation Charts. Dresser Industries, Houston, TX. 107 
Mahmoud, H. M. and AbouAshour, N. M. H.

Egyptian General Petroleum Corporation, EGPC, (1994): Nile Delta and North Sinai Fields, Discoveries and Hydrocarbon Potentials (a comprehensive overview) Cairo, Egypt, 387.

Freedman R. Chanh Cao Minh and Greg Gubelin., (1998): Combining NMR and density Logs for Petrophysical Analysis in Gas-Bearing Formations, paper II, SPAWLA 39th Annual Meeting, Colorado, 26-29 May.

Glover, P., (2014): the effect of clay on porosity and resistivity logs. in: Petrophysics MSc course notes , chapter 20, Leeds Univ., United kingdom,270.

Harms J. C., and Wray, J. L. (1990) Nile Delta. In: Said R (ed) The geology of Egypt. Balkema, Rotterdam, Netherlands, 329-343.

Nassar, M., Nijenhuis, I., Fattah, T. A. and Ramadan, A. E. (2012): Occurrence, character and origin of natural gases in the deepwater Nile Delta, Egypt: N. Afr. Tech. Conf. and Exhibition, Cairo, 23.

Popov, S. V., I. G. Shcherba, L. B. Ilyina, L. A. Nevesskaya, N. P. Paramonova, S. O. Khondkarian and I. Magyar, (2006): Late Miocene to Pliocene palaeogeography of the Paratethys

Rizzini, A., Vezzani, F., Cococcetta, V., Khalil, M. (1976): Stratigraphy and sedimentation of the Neogene-Quaternary section in the Nile Delta area, A. R. E. $5^{\text {th }}$ Expl Seminar Cairo, 327-34

Rouchy, J. M. and Caruso, A. (2006): The Messinian salinity crisis in the Mediterranean basin: a reassessment of the data and an integrated scenario: Sedimentary Geol., 188-189, 35 - 67.

Schlumberger, (1989): log interpretation principles applications, Schlumberger well services, 224

Steininger, F., and Rögl, F., (1984): Paleogeography and palinspastic reconstruction of the Neogene of the Mediterranean and the Paratethys.in J. E. Dixon and A. H. F. Robertson, eds., The Geological Evolution of the Eastern Mediterranean: Geol. Soc. Spec. Publ., 17, 659 - 668.

Thomas and Striber, (1975): The distribution of shale in sandstones and its effect upon porosity. SPWLA 16th Annual Logging Symposium Transactions, 33-36. 
طريقه متكامله للتقييم البتروفيزيائي لخزانات الحجر الرملي الطقلي لحقل سيميان -دلتا النيل- مصر

$$
\text { حسام محمود محمود و ناصر ابوعاشور }
$$

شركة رشيد للبترول و قسم الجيوفيزياء ، كلية العلوم ، جامعة عين شمس

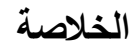

يتضدن البحث الحالي مجموعه متكامله من دراسات التراكيب الجيولوجية العامة لمنطقة حقل سيمبان الواقع في

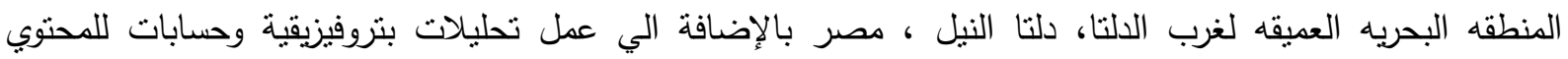

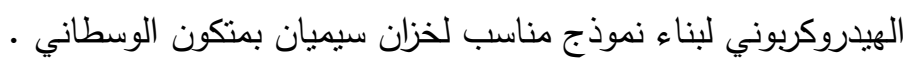

تم حساب معاملات المسامية والنفاذية وكمية الماء المشبعة للصخر وكذا كمية الغاز وذلك من خلال دراسة البيانات

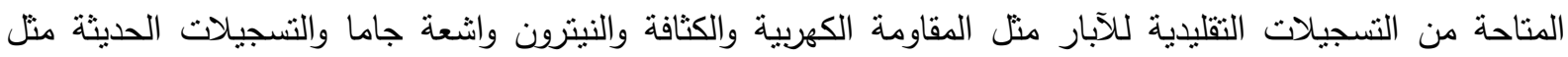
الرنين المغناطيسي النووي و FMI لعدد خمس آبار منهم ثلاثة آبار إستكثافية و اثثين آبار تتمية موزعة في حقل سيميان شملت الدراسة مقارنة بين النتائج المحسوبة من التسجيلات التقليدية و التسجيلات الحديثة للآبار حيث ان كل طريقه لها ميزاتها وعيوبها ولذلك تتاولت الدراسه الحاليه دراسه تكميليه تشمل جميع النتائج لاستتناج المخزون الاكثر احتمالا للخزان عن طريق استخدام ثلاث طرق لحساب الخواص البتروفيزيقيه لخزان سيميان شامله لكل البيانات والتسجيلات المتاحه وذلك لتقليل المخاطر المصاحبه لحساب المخزون الفعلي للخزان وما يترتب عليه في عمليه التتميه لحقل سيميان . 